\title{
Understanding Professional Service Delivery
}

\author{
Kate Walsh, Cornell University \\ Judith R. Gordon, Boston College
}

Purpose: The purpose of this paper is to apply concepts from organizational and social identity theories to theoretically consider different ways that professional service providers conceptualize their roles and deliver their knowledge.

Design/methodology/approach: The paper is a conceptual discussion to advance the understanding of professional service delivery, within the realm of service-quality research.

Findings: The field has yet to provide a clear understanding of what professional service delivery actually looks like. The paper offers propositions examining the process by which professionals identify with membership in their profession and firms that in turn, influence their expert-based self-concepts, the images they form of their clients as recipients of their knowledge, and ways they create the service exchange. The paper also considers the impact of professional and organizational identification on the types of clientele professionals may develop.

Research limitations/implications: The paper adds depth to the understanding of the complex process of expert-based service delivery. The ideas presented in this paper have implications for research in service-quality, specifically in understanding how and why professionals approach their client-interactions.

Practical implications: The ideas presented in this paper would be useful to professional service firms interested in understanding the role their firm's identity plays in ways its professionals conduct their work and the types of clientele they wish to attract.

Originality/value: The paper contributes to the service quality literature through conceptualizing professional service delivery. It represents a step in acknowledging the role of professional delivery in influencing service outcomes and in developing the theoretical rationale as to why different approaches exist.

Keywords: Professional services, Service delivery, Doctors, Lawyers, Financial services

Paper type: Conceptual paper 


\section{Introduction}

The service organization has become a predominant form of business in the USA, among other countries, and by 2005 , contributed over 68 percent to the gross domestic product (US Bureau of Economic Analysis, 2006). While services represent many forms of businesses, including financial services, professional, health care, and entertainment, to name a few, extensive research has focused on transactional service encounters between customers and employees, such as those that occur in convenience stores, fast food restaurants, supermarkets, and banks (Leidner, 1993; Mars and Nicod, 1984; Rafaeli, 1989; Schneider et al., 1980; Sutton and Rafaeli, 1988). Much of this focus has been on how to organize and empower low-skilled employees to manage the temporary, impersonal, and often nonrecurring interactions with customers (Bowen, 1986; Bowen and Ford, 2002; Bowen et al., 1999; Bowen and Lawler, 1992, 1995). For example, within the field of services marketing, a stream of research has examined determinants of service quality based on the seminal work of Parasuraman et al. $(1985,1988)$, and most empirical studies have examined service quality in the context of these more transactionally based encounters with customers (Bitner et al., 1990; Cronin and Taylor, 1992).

Although an understanding of transactional service encounters, particularly the components of quality service delivery, is important, this focus represents only one dimension of services (Bowen and Jones, 1986; Gutek, 1995). We understand less about ways that professional service providers, such as doctors, lawyers, and financial planners, create similar quality-oriented exchanges with their clients. The purpose of this paper is to examine how these professionals might do so. This paper seeks to add to the understanding of services, specifically professional services, through theoretically considering the different ways that service professionals conceptualize their roles and deliver their knowledge.

Professionals offer their clients a sophisticated, knowledge-based expertise (Greenwood and Empson, 2003; Maister, 1993), and the relationships these professionals create with their clients are the medium through which they impart this expertise to solve their clients' problems (Gutek, 1995; Reihlen and Apel, 2007). While researchers agree that building strong client relationships is crucial to any service firm's success (Guenzi and Pelloni, 2004; Reichhold, 1993; Rust and Zahorik, 1993; Svensson, 2006; Varva, 1992), the professional-client service exchange, unique to professional service firms (PSFs), has received less attention. (A notable exception is Brown and Swartz's (1989) examination of patients' satisfaction with their physicians.) In other words, while researchers acknowledge that the process of service delivery - or the application of knowledge to solve a client's problem - is critical to a service firm's success, the field has no clear grasp on what professional service delivery actually looks like in 
practice and how it is tied to service outcomes (Dabholkar and Overby, 2005). This is likely because the service interaction requires a high degree of customization and even personal judgment on the part of the professional (Jaakkola and Halinen, 2006; Reihlen and Apel, 2007; Sharma and Patterson, 1999; Verma, 2000). As a result, the ways in which professionals deliver their expertise is highly variable and remains a relatively unexplored area. So too, there exists a lack of service-based research that explores the role the service providers' perspectives and specifically considers the impact of employees' attitudes and behaviors on their service orientations (Saura et al., 2005; Svensson, 2006).

In this paper, we apply concepts from organizational and social identity theories to examine the role of identification in shaping different service delivery approaches. Specifically, we consider in what ways service professionals identify with membership in their profession and their firms that in turn, influence their work-based self-concepts, the images they form of their clients, and ways they create the service exchange. We also consider how this process ultimately shapes the types of clientele that professionals develop. This work provides a different perspective from studies of professional services that examine more the results of successful client-based relationships, than the role service delivery plays in creating these relationships (Levinthal and Fichman, 1988). Our goal is to develop theoretical propositions that can help both researchers and practitioners further understand the complex phenomenon of professional service delivery (Karantinou and Hogg, 2001).

This paper has four sections. The first section reviews research on professional service delivery; we show that current research offers conflicting ideas on ways service professionals should interact with their clients and provide their expertise. The second section applies theories of social and organizational identity to explain differences in professionals' work-based self-concepts. In the third section, we explore the impact of identity, first on the images professionals hold of their clients and second on ways they create the service exchange. We also discuss the types of clientele they develop. The final section concludes with the implications of our ideas for research in both service-based theory and practice.

\section{Professional Service Delivery}

\section{Research on Professional Service Delivery}

Professional services are delivered to clients through on-going relationships in which professionals and their clients interact to develop a shared history of the clients' needs in order to solve their problems (Jaakkola and Halinen, 2006; Sharma and Patterson, 1999; Svensson, 2006). Owing to its high-degree of customer contact, as well as the level of individual judgment required by the professional, this form of service is considered the most intangible (Jaakkola and Halinen, 2006). 
Ultimately, as "counselors," "advisors" and "experts" (Reihlen and Apel, 2007), professionals apply their knowledge to specific information about their clients' needs to deliver a quality service (Gutek, 1995; Verma, 2000). The relationships that service professionals create and sustain with their clients act as the medium for exchanging the knowledge-based human capital (the resource) for fees (the valued outcome) (Coff, 1997; Pfeffer and Salancik, 1978). Indeed, the high degree of asset specificity, that is, unique knowledge transfer, involved in professional service encounters, coupled with its moderate-tohigh degrees of risk and investment, make the establishment of familiar relationships the most efficient way of organizing the resource exchange (Griesinger, 1990). As a result, these relationships are viewed as sources of competitive advantage for both the professional service provider and his or her firm (Sharma and Patterson, 2000). For example, an important dilemma for PSFs is that clients can be more loyal to the professional than to the firm. Thus, if professionals leave their firms, they can potentially take valuable revenue sources with them (Coff, 1997). Professional-client relationships are the context for expert-based service delivery and are central to a PSF's success.

Interestingly, researchers offer conflicting arguments about ways that professionals should approach their clients and impart their expertise. These arguments range from encouraging professionals to connect and build relationships with clients (Noddings, 1984) to suggesting that professionals should detach from their clients, especially emotionally, and even express arrogance when delivering professional work (Pierce, 1996). For example, Benner and Wrubel's (1989) work on caring in the nursing profession discusses the criticality of connecting on both a cognitive and emotional level with the patient. Similarly, research in relationship marketing argues that conveying trust and commitment to customers, as well treating them in fair and respectful ways, are crucial to establishing the long-term, profitable relationships that result in high repurchase behaviors (Berry and Parasuraman, 1991; Garbarino and Johnson, 1999; Sharma and Patterson, 1999, 2000; Seiders and Berry, 1998). These types of relational exchanges not only solve customers' core needs, such as when a dentist fills a cavity, but they also provide customers with additional social benefits, including engendering feelings of familiarity and rapport (Berry, 1995). Ultimately, trustworthy, long-term, exchanges reduce customers' risk and uncertainty and ease their decision-making process (Gwinner et al., 1998).

Yet, other researchers argue that more negative expressions of behaviors and emotions by service professionals are useful to enhancing professional service delivery. Some clients perceive traits such as arrogance and intimidation to be signals of expertise and in some occupations, such as law, professionals are taught to use gamesmanship to dominate their clients and control the interaction (Pierce, 1996). In fact, some clients willingly treat their service professionals in deferential, 
accommodating ways. One only has to think of patients waiting hours after their scheduled appointments to see their doctors, or lawyers quickly and unabashedly grilling potential clients to understand what this concept looks like in practice. In return for receiving superior expertise, clients are expected to accept and accommodate "(professionals) large egos" and receive less than respectful treatment (Gutek, 1995). In fact, physicians are being taught how to use communication skills to better connect with their patients and ensure they are taking the appropriate time to diagnose their patients' conditions (Chase, 1998). Ultimately, professional providers, as the holders of complex knowledge, have some degree of control over the clients (Reihlen and Apel, 2007).

Because this research on professional service delivery offers conflicting ideas, approaches to providing an expertise are worth exploring in greater detail. We do so through examining how professionals may conceptualize imparting their knowledge to their clients, through interacting with them. We offer that professionals' approaches to delivering their expertise are reflected in their selfconcepts in the context of their work, the associated images they hold of their clients and ways they create the service exchange (Figure 1) Social and organizational identity theories are applied to develop the types of service delivery approaches professionals may use, and these theoretical underpinnings are discussed next.

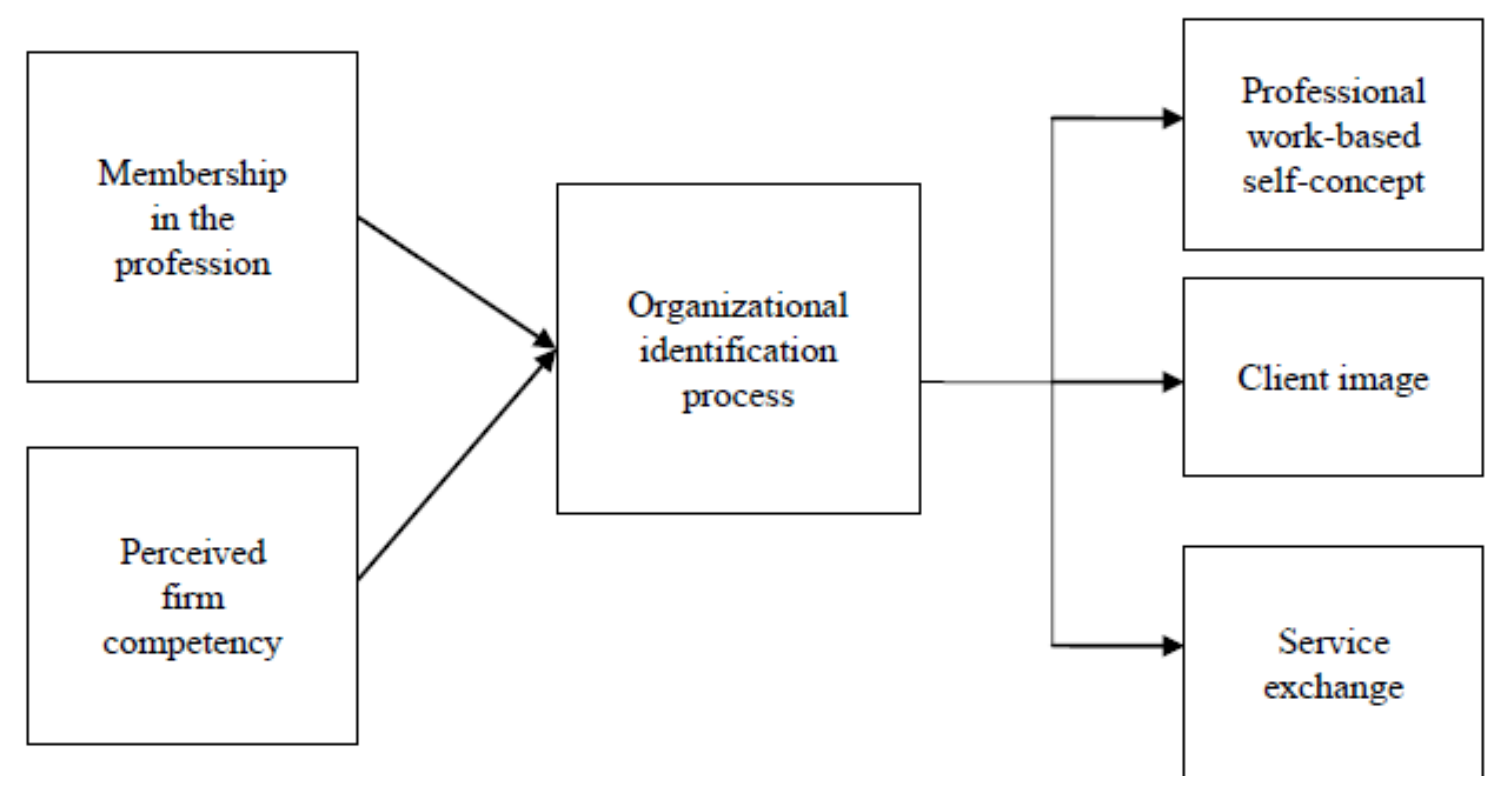

Figure 1. The process of identification and its impact on professional service delivery 


\section{Professional's Work-Based Self-Concepts}

\section{The Organizational Identification Process}

Social identity theory is a useful lens for understanding ways professionals may approach their service delivery because it helps clarify how professionals may think of themselves in context of interacting with their clients. This theory seeks to explain how and why individuals create and sustain particular aspects of their self-concept (in this case, those aspects related to their work and career). Selfconcept refers to a conceptual construction or schema that an individual holds about his or her roles, relative to others' roles (Brewer, 1991; DeSteno and Salovey, 1997; Reitzes and Mutran, 2002). Characteristics of an individual's social environment influence the various aspects of his or her selfconcept (DeSteno and Salovey, 1997).

According to social identity theory, individuals define themselves by comparing themselves to others and in doing so, they classify themselves and others into different and multiple social groups (Abrams and Hogg, 1990; Hogg et al., 1995; Tajfel, 1982; Tajfel and Turner, 1985; Turner, 1982; Turner et al., 1987). They simultaneously attach value to these groupings (Pettigrew, 1986).Thus, social identity represents an individual's sense of attachment to, and differentiation from his or her community (Hewitt, 1989). Individuals use these classifications to distinguish themselves as different from outgroup members, yet at the same time, as similar to in-group or desirable group members (Ericson, 1980; Hogg and McGarty, 1990). Thus, their social identity helps individuals make sense of their social environment, as well as locate a place for themselves within it.

Two key social groups for which professional service providers may identify with membership and use to define aspects of their work-based self-concepts are their professions and their firms. Organizational identity theory, which explores the process of identification, helps explain the reasons why individuals may choose to do so. Defined as "the degree to which a member defines him- or herself by the same attributes that he or she believes defines the organization" (Dutton et al., 1994, p. 239), the organizational identity process helps individuals elaborate their self-concept by answering the question of "Who am I?" in the context of their work (Albert and Whetten, 1985; Corley et al., 2006). Researchers argue that individuals will use their organizations' distinguishing characteristics and status relative to other organizations to define their self-concept (Dutton et al., 1994; Pratt, 1998; Tyler, 1999). Specifically, members will identify with their organizations to the degree they perceive their organizations to be prestigious, because they believe that prestige will enhance their self-concept in a desirable way (Pratt, 1998; Tyler, 1999). Phrased differently, individuals will be attracted to an 
organization's perceived identity if they believe that identity confers positive qualities on them, specifically if it augments members' sense of distinctiveness and self-esteem, and in turn makes their self-concept more positive (Dukerich et al., 2002; Dutton et al., 1994).

Membership in the Professions and Professional Work Identity

Part of the identification process for members is determining the identity of their work-based groups. One defining characteristic of service professionals is that they are members of a salient group outside of their own organizations, namely their professions. As research in the professions indicates, for professionals, membership in their association or fellowship of peers beyond the organization may act as a strong and important influence on their work identity (Covaleski et al., 1998; Dukerich et al., 1996). Occupations such as the professions, where members must possess an esoteric and expert-based set of knowledge, "foster a feeling (or culture) of specialness" (Trice, 1993, p. 24). As a result, professional work provides members with a favorable self-concept.

Key aspects of the professions and professional work contribute to the positive distinction conferred to its members. Professional work entails a high degree of knowledge-based expertise or human capital (Barber, 1965; Winter, 1988). Professionals develop their expertise through training and experience (Abbott, 1988). Both are considered assets to the professional and are signals of the abstract knowledge required to do professional work. Acquiring this abstract knowledge, as demonstrated through holding a degree and accumulating years of experience, provides professionals with the necessary credibility to accomplish their work. The client needs the knowledge, and through training and experience the professional provides it. As Hughes (1965, p. 2) suggests, "professionals profess" or share their knowledge with those who need it. In fact, the professional views imparting knowledge to all "outgroup" individuals (including clients) as his or her calling and service to the community (Barber, 1965). In addition, professional associations establish:

[.. . ] rigorous socialization experiences [. . .] underscoring that the knowledge, skills and abilities are not easily learned by just anyone and that they require a special learning experience and a special person to grasp them (Trice, 1993, p. 26).

As a result, professional members tend to use one another as a reference group in not only admitting new members, but in evaluating the contribution of current members - and hence each member's level of expertise (van Maanen and Barley, 1984). The professional is committed to these processes as they help maintain the profession's high levels of specialized knowledge, as well as maintain members' enhanced status outside the profession (Barber, 1965; Winter, 1988). 
This literature implies that as result of being a member of a professional group, service professionals are likely to think of themselves as intelligence-based experts. We suggest they are likely to think of themselves in this way because for professionals, a main source of distinction from out-group members is that they hold uncontested authority over their clients and are the unquestionable experts (Barber, 1965; Carr-Saunders and Wilson, 1941). Professionals are likely to assume they know better than their clients what their clients need and desire from them. In fact, as Hanlon (1997, p. 125) argues, "the professional controls the interaction with the client and translates clients' desires into a professional metalanguage and/or explains to clients what is possible in their situation." So too, Grey (1988, p. 570) offers:

The power of professions stems from their ability to exclude others from the technical and legal based on their practices [... ] Professionals are able not just to exert control over bodies of knowledge but also to define what that knowledge properly consists of.

The strength of the professional's ability to control knowledge as an expert leads to our first research proposition:

P1. The more service professionals identify with membership in their profession, the more likely they are to define themselves as intelligence-based experts.

\section{A Firm's Identity and Human Capital Competencies}

In addition to being members of their profession, however, service professionals are also members of their firms. We argue that this membership also shapes the work identity professionals hold. At the firm level, an organization's identity refers to an organization's central, distinctive, and enduring character that is typically anchored in its mission (Albert and Whetten, 1985). An organization's identity defines the essence of a firm (Gioia, 1998); it is reflected in the organization's core and lasting values, and it is enacted through its programs, policies and procedures (Whetten, 2006). Phrased a different way, an organization's identity represents a firm's distinguishing features (Corley, 2004), that is, what makes a particular organization unique from other firms (Whetten, 2006).

Because an individual's need for self-enhancement and a positive self-concept drives his or her identification with an organization (Hogg et al., 1995), organizational members will likely determine their organization's identity by focusing on what makes their own organization central, distinct, and enduring, relative to other organizations (Dukerich et al., 2002). We argue that in determining these characteristics, members will likely turn to their firm's strategic focus. Our arguments are rooted in the idea that an organization's central, distinct, and enduring characteristics are reflected in its strategic 
competencies. This connection occurs because an organization's strategic competencies represent the services offered by an organization that are superior to the competitions", that is, the "patterns [...] of resource and skill deployment that will help it (an organization) achieve its goals and objectives" (Hofer and Schendel, 1978, p. 25) and that act as the firm's source of competitive advantage (Douglas and Ryman, 2003; Nelson and Winter, 1982). Because they represent the source of advantage, these competencies provide members with an affirming organizational identity.

A key differentiating competency and source of sustained advantage in PSFs, who sell knowledge as a form of service, is human capital or the knowledge and skills held by an organization's members (Barney, 1991; Becker, 1993; Grant, 1996; Hitt et al., 2001; Morris and Empson, 1998). PSFs create value when its members use their intellectual resources to develop and offer knowledge central to the organization's purpose (Hitt et al., 2001; Nelson and Winter, 1982; Nonaka, 1994, Teece et al., 1997). Because this human capital is tacit, complex, and often firm-specific, it is difficult to imitate; hence it acts as a more sustainable source of advantage (Barney, 1991; Black and Boal, 1994; Coff et al., 2006; Hitt et al., 2001; Lane and Lubatkin, 1998; Makhija, 2003; Mowery et al., 1996; Peteraf, 1993).

We argue that because human capital represents a competency that contributes to a PSF's distinct competitive advantage, professionals who identify with firm membership will likely use this human capital competency to shape the work-based component of their self-concept. This competency helps professionals to define themselves in context of their work, and it enables them to enact roles particular to their client interactions. We next become specific with our arguments and explore which firm-based human capital competencies professionals use to shape their self-concepts.

There exist two types of PSFs - professionally oriented and market-oriented. Professionally oriented service firms represent a group of professionals organized to promote and share codified and specialized knowledge gained through training in the profession and honed through apprenticing in the firm. Market-oriented firms, on the other hand, are enterprises whose expressed goals are to remain competitive, increase revenues, and enhance wealth and value for its owners or partners (Bunderson et al., 2000). Each type of firm develops specific human capital competencies that contribute to advantage and distinction. We argue that a professionally oriented firm develops a human capital competency based on superior knowledge distinction (a knowledge-based expertise) and that a market-oriented firm develops a similar competency based on either a client-oriented service orientation (a collaborative expertise) or an efficiency-based orientation (an efficiency-based expertise). We also suggest these competencies will be used by professional service providers to create the work-based component of 
their self-concept; specifically, when imparting their expertise, professionals are likely to think of themselves as knowledge-based experts, collaborative experts, or efficiency-based experts.

The professionally oriented firm, distinguished by its knowledge-based human capital. Similar to the professions, a professionally oriented firm develops a human capital competency based on superior knowledge distinction. These firms cultivate high degrees of asset specificity or unique, specialized knowledge and skills in the content of their field; for example, a medical practice may house the most renowned, "highly skilled" doctors in the profession. Firms that do so are akin to what Coxe et al. (1987) refer to as "practice-centered businesses," and they develop their reputation and build their advantage through their specialized and complex knowledge-based competency (Reed and DeFillippi, 1990). This competency is based on professionals' membership in their profession. The goal of the firm is to sell the specialized knowledge related to the abstract content of the field (Winter, 1988).

We argue that because this competency of specialized knowledge and skills contributes to a PSF's distinct competitive advantage, professionals who identify with firm membership will likely use it to shape the work-based component of their self-concept. This competency fuels professionals' need for prestige, distinction from out-group members and self-enhancement (Dutton et al., 1994). Translating the firm-competency to the individual level means that in a firm that develops a specialized, complex knowledge-based competency, its service professionals offer their intelligence for sale. This tacit expertbased knowledge is used to solve clients' sophisticated problems. Our logic is based on research in the professions, which offers that professionals hold authority as experts in their fields (Barber, 1965). As a result, we suggest to the degree service professionals identify with their firm's human capital competency as providing specialized, complex knowledge, the more likely they are to think of themselves as intelligence-based experts who share their knowledge and skills with those who need and will benefit from it. Hence, we propose the following:

P2. The more service professionals identify with their firm's human capital competency of providing specialized, complex knowledge, the more likely they are to think of themselves as intelligence-based experts.

The Market-Oriented Firm Distinguished by its Client-Based Human Capital.

A market-based firm resembles what Coxe et al. (1987) refer to as a "business-centered practice." Market-based firms that cultivate an enhanced reputation and develop distinguishing servicebased competencies create and sell two forms of human capital. The first type of human capital emphasizes client-oriented service delivery, characterized by the ability to actively service clients and so 
meet their complex needs. The second type of human capital stresses highly efficient service delivery, characterized by a relatively simple product delivered in a very consistent manner (Coxe et al., 1987; Winch and Schneider, 1993).

Firms characterized by their strong client-oriented service delivery develop their human capital competency around their ability to create tacit routines and relationships with their clients, as they work to solve clients' problems (Maister, 1993; Mills et al., 1983). Thus, these types of firms develop high degrees of unique advantage around the processes by which they create and sustain long-term client relationships (McLean Parks et al., 1998). Specifically, these firms learn and embed in their client interactions the most effective way of developing and maintaining their client base, usually through collaborating with their clients to meet their clients' unique needs. Successful firms of this type view their consultations as "client-centered partnerships" (Old, 1995), whereby the consultant and client are interdependent in a mutual and balanced way (McGivern, 1983). Indeed, researchers suggest that competitive professional services firms are defined by their commitment to learning and adapting to the clients' needs (Reihlen and Apel, 2007). These firms cultivate their reputation and build their advantage around this strong and active service orientation.

We argue that if professionals identify with this competency, they are likely to use it to create the work-based component of their self-concept. Once again, our rationale is based on the concept that this competency will act as a source of prestige to its members and thus be an attractive source of a work identity (Dukerich et al., 2002; Dutton et al., 1994). Translating the firm competency to the individual level means that in a firm with a client-focused orientation, service professionals would work with clients to discern and meet the clients' unique needs. In doing so, they will likely think of themselves as collaborative experts. This argument is based on the concept that if a firm distinguishes itself based on its specialized process of delivering a service, its professional members who identify with this competency will likely think of themselves as experts of this specialty. As such, they will view themselves as skilled collaborators. Stated more formally, we propose the following:

P3. The more service professionals identify with their firm's human capital competency of providing a client-focused orientation, the more likely they are to define themselves as collaborative experts.

The market-oriented firm distinguished by its efficiency-based human capital. Rather than focus on servicing clients' needs, some market-based firms build their competitive advantage through their offering a product low in knowledge and relationship asset-specificity and high in efficient service delivery. For example, a for-profit medical clinic that dispenses flu shots may focus on efficiency as a 
competency, rather than honing the field of infectious diseases or meeting the specific, unique needs of their long-term clients. These efficiency-focused firms are successful through their mass production of a service. They cultivate their reputation and develop firm heterogeneity around their ability to create streamlined processes that lead to cost savings and greater profitability. If professionals identify with this firm-based competency, we argue they will use it to create the part of their self-concept that relates to their work. Translating the firm competency to the individual level means that if the firm develops a streamlined service delivery advantage, then service professionals will likely view themselves as efficiency-based experts, who provide a mass product to many customers. Our rationale is based on the idea that these professionals will again focus on their firm's positive competency to create a positive self-image. If this competency is rooted in mass production, those who identify with firm membership will likely think of themselves as skilled in delivering a quick, high-volume product. As a result, we offer the following:

P4. The more service professionals identify with their firm's distinguishing human capital competency of providing streamlined service processes, the more likely they are to define themselves as efficiencybased experts.

\section{Client Images, the Service Exchange and Developing a Clientele}

\section{Client Images}

Organizational identity theory contends that individuals who choose to identify with professional and firm membership think and behave differently as a result (Ashforth and Mael, 1996; Bartel, 2001; Kreiner and Ashforth, 2004; Pratt, 1998). This is because an organization's identity represents an ideology that provides members with performance guidelines, especially when interacting with members outside the group (Trice, 1993). These performance guidelines are in the form of roles, or social cues, and they bestow a sense of purpose, as well as suggest to individuals how to think about and act toward others, especially out-group members (Hogg and Abrams, 1988, 1990; Thoits, 1991). As individuals compare themselves to out-group members, they develop an idea of what they should offer to as well as expect from others (Kramer, 1991). Thus, by adopting a particular role associated with identifying with a group, an individual also develops views about the expected roles associated with outgroup members (Charon, 1992; Schlenker, 1980). More specifically, a professional who identifies with his or her firm develops a view about the expected roles associated with his or her clients. 
Concepts about roles, specifically determinants of role behavior, have been used in the services marketing literature to delineate the "rules of behaviors" that service providers and customers use to engage with one another (Broderick, 1999). In fact, as the context for delivery, service encounters have been viewed as role performances and service providers as the "social actors" who are expected to display behaviors appropriate to enacting their roles (Solomon et al., 1985). To successfully perform their production roles, service providers need their customers to behave in a particular manner (Bitner et al., 1997; Troyer et al., 2000). These behaviors are termed "role scripts," and they delineate the boundary conditions around the dyadic interaction (Broderick, 1999). Thus, role theory, under the rubric of services marketing, suggests that service providers form expectations around the role they expect their customers to adopt, as together they produce the service for sale.

In the context of professional service delivery, we offer that individuals who identify themselves as members of their profession and firms are likely to form images of outsiders, specifically their clients, based on the roles service professionals expect their clients to enact. In addition, we argue these images are based, not only on what membership in the professions dictates, but are also based on the degree to which professionals identify with their firms' distinguishing competencies. In particular, we examine three specific images: clients as non-experts, equal co-producers, and transactional customers.

Clients as non-experts. We suggest that to the extent that professionals identify with membership in their profession, they will not only view themselves as intelligence-based experts, they will likely hold the opposite view of their clients, as non-experts of the professional's specialty. We argue they will develop this image of their clients because in this way, clients reinforce the professionals' roles as experts. For professionals, a main source of distinction from out-group members is that they hold uncontested authority over their clients (Barber, 1965). Professionals are likely to assume they know better than their clients what their clients need from them and would expect their clients to accept the professionals' expertise (Hanlon, 1997). Professionals are apt to develop this image of their clients because they believed that it helps them and their clients enact an efficient exchange, whereby clients rely on the professional to know how to best solve the clients' problems. Thus, we suggest that, to the extent service professionals identify with professional membership, the more likely they are to hold an image of their clients as non-expert recipients of their services. Stated more formally:

P5a. The more service professionals identify with membership in their profession, the more likely they are to view their clients as non-experts of the professionals' specialties. 
Similarly, if professionals identify with the specialized, complex knowledge-based distinguishing competency of their firms, they will likely hold identical views of their clients as non-expert recipients. This view occurs because this form of competency would also confer an expert-based identity to firm professionals. Again, to enact this identity, professionals would expect their clients, as out-group members, to adopt congruent roles, specifically to act as non-experts, whose primary task is to receive the service. Phrased more formally:

P5b. The more service professionals identify with their firm's human capital competency of providing specialized, complex knowledge, the more likely they are to view their clients as non-experts of the professionals' specialties.

Clients as equal co-producers. Professionals who identify with their firm's client-focused distinguishing competency are also likely to develop corresponding images of their clients based on ways their clients can help professionals enact their roles. To be successful as collaborative experts, service professionals need their clients to act in ways that enable these professionals to focus on and meet each client's unique needs. To do so, professionals will likely expect their clients to work interdependently, openly sharing information that will enable these professionals to accomplish this goal. Research in the consulting literature has suggested these distinct roles by offering that the consultant and client are interdependent. Effective consultants respect and empower their clients to act as equals, especially in their decision making (Clark and Salaman, 1998; Haug, 1994; McGivern, 1983; Schein, 1997). By doing so, clients work together with their professionals to jointly diagnose and solve their problems and in doing so, both parties learn from one another. This consultative approach suggests that professionals will likely view their clients as knowledgeable and equal out-group members who co-produce the service with them. Clients are crucial to the quality of the service product. Thus, we suggest that, to the extent service professionals identify with their firm's human capital competency of providing a client-focused orientation, the more likely they are to hold an image of their clients as equal co-producers, actively involved in creating the service and, as a result, ultimately being served. Hence, we offer the following:

P6. The more service professionals identify with their firm's human capital competency of providing a client-focused orientation, the more likely they are to view their clients as equal co-producers of the service product.

Clients as transactional customers. Service professionals who identify with their firm's streamlined human capital competency also likely have role expectations for their clients. These expectations are 
rooted in the logic that, to maintain an efficiency-based self-concept and enact the role associated with identifying with their firms, professionals need their clients to act more as transactional customers, who quickly receive the service and leave the interaction. These professionals do not expect their clients to act as relational partners and, in fact, they may view them as faceless, mass recipients of their commodity, whom they may or may not see again. For example, a nurse who dispenses flu shots at a clinic will not differentiate among patients with different medical profiles, but will instead likely view them as part of a large group of similar customers (Gutek, 1995; Gutek et al., 2000). These service providers would have minimal service expectations of their clients. Thus, we argue that to the extent service professionals identify with their organization's streamlined service delivery competency, the more likely they are to hold an image of their clients as transactional customers. Phrased more formally:

P7. The more service professionals identify with their firm's distinguishing human capital competency of providing stream-lined service processes, the more likely they are to view their clients as transactional customers.

\section{The Service Exchange}

Based on the degree to which they identify with membership in their profession and firms, we have identified three characteristics of service providers' self-concepts and the associated images of clients that these service professionals may hold. Taken together, they suggest specific role performances or ways to interact with clients in a service exchange. Specifically, we propose that depending on which organizational competency they use, as part of identifying with professional and organizational membership, the nature of the exchange that professionals create with their clients will differ. As Gutek (1995) has suggested, multiple exchanges or relationships with clients can be one of two types. The first is a service relationship, whereby a client and the individual service provider develop a history of shared exchanges that over time, guide and structure ways they exchange resources. The second is a pseudorelationship, defined as occurring when a client and the provider's organization develop a similar history of shared exchanges. The primary difference between the two is that when clients develop a pseudorelationship with a particular organization, they do so through interacting in an impersonal and transactional way with different service providers within that organization (Gutek et al., 1999, 2002).

We propose that professionals who identify with their membership in their profession, as well as with their firm's competency of providing either specialized, complex knowledge or a client-focused orientation, will likely use multiple, relationally based service exchanges to deliver their expertise to 
their clients. Developing a shared history of interactions will enable these professionals to enact workbased aspects of their self-concept and provide their service in the most efficient manner. Repeated professional-client interactions will allow the professional to develop an understanding of the client's needs, such that he or she can accurately apply abstract knowledge to diagnose and solve the client's problems, key aspects of professional work (Abbott, 1988). In addition, professionals who identify with their firm's client-focused orientation need to develop a shared history to jointly customize their services with their clients.

Alternatively, professionals who identify with their firm's competency of providing streamlined processes will likely establish transactionally based exchanges or pseudorelationships with their customers (Gutek et al., 1999). To enact the work-based component of their self-concept in delivering their expertise, these experts would have no need to interact with the same clients in a continuous manner and instead would benefit from structuring their services through quick and efficient encounters. Hence, we offer:

P8a. The more professionals identify with membership in their professions, the more likely they are to use multiple, relationally based exchanges to provide their expertise.

P8b. The more professionals identify with their firm's human capital competency of providing either specialized, complex knowledge or a client-focused orientation, the more likely they are to use multiple relationally based exchanges to provide their expertise.

P8c. The more professionals identify with their firm's human capital competency of providing steamlined service processes, the more likely they are to use transactionally based exchanges or pseudorelationships to provide their expertise.

\section{Developing a Clientele}

It is important to note that our assertions are not as straightforward as they may appear at first glance. When identifying with their organizations, individuals form perceptions of what they believe to be their organization's central, enduring and distinctive character (Ashforth and Mael, 1996; Pratt, 1998). In part, because identity is a socially constructed phenomenon, it is unlikely that individuals will perceive their organization's identity in identical ways (Ashforth and Mael, 1996), and some will more strongly identify with their organization's membership than others (Dukerich et al., 2002). In addition, individuals can hold multiple ideas about their organization's central character and identify with their organizations in numerous ways (Kramer, 1991; Pratt, 2000; Pratt and Rafaeli, 1997). They can also draw on membership in other social groups to shape the work-based aspects of their self-concept, even when 
working (Brewer and Pierce, 2005). Thus, the strength to which individuals identify with their organizations, as well as the degree to which they hold multiple identities, can shape unique approaches to service delivery and ultimately the types of clientele that professionals develop.

Yet, in better understanding expert-based service delivery, we do believe that central concepts can and should be delineated. Social identity theory suggests that individuals hold some identities more strongly than others (Kramer, 1991) and this strength is based on the attractiveness of the identity (Dukerich et al., 2002). We argue that professionals may identify with membership in their profession, as well as with membership in their firms, based on all three organizational competencies, with varying degrees of strength. In the context of creating relationships with clients and delivering an expertise, professionals' identity strength will likely influence their work-based self-concepts, their related images of clients, the ways the create the service exchange and ultimately the type of clientele they develop. This degree of strength may cause professionals to de-select clients. It may also impact their ability to read signals from clients about their human capital expectations and adapt their identity accordingly. Specifically, we argue that if professionals strongly hold their identities with their professions and firms, these identities will dominate the ways professionals think about themselves as it relates to their work. As a result, it will be difficult for these professionals to adapt their work-based self-concept, their client images, and the service exchange to their clients' differing expectations and needs. For example, if a doctor strongly identifies with his practice's knowledge-based competency, it may be difficult for him to think of himself as anything other than an intelligent expert, even if his clients expert more of a collaborative expertise. The mismatch of client expectations against the service delivery may ultimately cause either the professional or client to de-select one another. Eventually, this type of professional likely will attract, retain, and build a specialty serving one type of client.

In contrast, other professionals may identify with their organization's membership more flexibly. Such professionals may be able to discern their clients' signals about their human capital expectations and, based on these expectations, identify with different distinguishing competencies they perceive their firm to have honed. They may shift the aspect of their work-based self-concept that identifies them as intelligence-based, collaborative, or efficiency-based experts, and their related client images, depending on what they believe their clients expect from them. As a result, these professionals may develop strategies to respond to clients with non-congruent images in ways that result in successful service delivery. Ultimately, these professionals will be more likely to build a practice that meets the needs of a wide variety of clients. Hence, we propose the following: 
P9. The more flexible their identification, the more likely service professionals will be able to adapt their self-concept, client image, and the service exchange and build a practice that meets the varying needs of a variety of clients.

\section{Implications for Service Research}

This paper has identified ways service professionals approach imparting their expertise, as illustrated in Table I, which summarizes what we suggest are three critical components of approaches to professional service delivery. Through identifying ways service professionals view their work-based selfconcept, their client images and the service exchange, we ask and begin to answer a critical and previously ignored question. The services field has yet to untangle the intangible, often complicated relationship between professionals and their clients. The implicit assumption in the literature has been that professionals' content-based expertise is the predominant driver of their success. As a result, we understand very little about why and in what specific ways some professionals are outstanding at delivering their knowledge. Our application of organizational identity theory is an attempt to understand how service professionals think of themselves and their clients in the context of the service exchange, why they have such perceptions, and how these perceptions affect the ways professionals deliver their expertise and ultimately build a practice. Thus, this work represents an initial step in not only acknowledging the role of professional delivery in influencing service outcomes, but also in developing the theoretical rationale about why different approaches exist. In doing so, it represents one way research from other fields can expand our understanding of services (Pilkington and Chai, 2007). It also answers Svensson's (2006) call for an increased abstraction of the service quality concept.

Table 1. The impact of professional and organizational identification on professional service delivery

\begin{tabular}{llll}
\hline & $\begin{array}{l}\text { Professional work-based } \\
\text { self-concept }\end{array}$ & Client image & $\begin{array}{l}\text { Service } \\
\text { exchange }\end{array}$ \\
\hline $\begin{array}{l}\text { Membership in the profession } \\
\begin{array}{l}\text { Specialized and complex } \\
\text { knowledge }\end{array}\end{array}$ & $\begin{array}{l}\text { Intelligence-based expert } \\
\begin{array}{l}\text { Perceived organizational competency } \\
\text { Specialized and complex }\end{array}\end{array}$ & Non-expert \\
$\begin{array}{l}\text { knowledge } \\
\begin{array}{l}\text { Client-focused orientation } \\
\text { Streamlined service processes }\end{array}\end{array}$ & $\begin{array}{l}\text { Collaborative expert } \\
\text { Efficiency-based expert }\end{array}$ & $\begin{array}{l}\text { Relationship } \\
\text { Transactional } \\
\text { customer }\end{array}$ & $\begin{array}{l}\text { Relationship } \\
\text { Pseudo- } \\
\text { relationship }\end{array}$ \\
\hline
\end{tabular}


It is important to note that in presenting a professional/market oriented dichotomy, we are examining ways professionals identify with their firm's strategic, human capital competencies. In this paper, we do not consider the idea that many PSFs likely try to be both professional and serviceoriented, blending both a professional and market orientation. Certainly this combination can describe some medical practices, for example, that now encourage their doctors to undergo training in patientservice. We argue, however, that, regardless of what the firm's competency is, professionals will look to their firm's human capital primary specialty to create a salient, central identity for themselves - i.e. that of a knowledge-based expert, collaborative expert or efficiency-based expert. This identity will drive the ways in which these professionals deliver their expertise.

Our ideas could be extended to inform the services literature in a number of provocative ways. In addition to empirically testing these propositions with samples of different professional groups, future work could more extensively explore the behavioral implications of identifying with organizations. For example, research could examine the specific behaviors that service professionals use in their client exchanges and explore the ways these behaviors enable or disable professionals' abilities to deliver their expertise. In addition, research could also examine professionals' abilities to discern signals from their clients about clients' service expectations. Such studies could inform both service research and its practice. For example, a widely known frustration for physicians is the "door-knob syndrome," which occurs as the physician gets ready to end the interaction and the patient finally begins to discuss his or her real problem. Research that examines the professional's ability to read signals and use exchange behaviors in an efficient way, could work to address this challenge.

Other ways to extend these ideas could be to explore the implications of professionals who identify with membership in non-professional groups, such as those based on gender, nationality, religion or other salient social groups. This type of work would help us understand the ways membership in these types of groups, in addition to organizational membership, influences service delivery. For example, a female financial planner might approach interactions with her clients in a different manner from her male counterparts, even though both may be members of the same professionally based firm. Gender differences in the law profession are the topic of examination for Pierce $(1995,1996)$ in her study of "rambo litigators." Investigating the impact of membership in multiple social groups lends complexity, but also validity, to the impact of identity of professional service delivery.

Finally, additional ways to extend our work would be to explore what happens when a professional breaks out of an identity-image link. For example, what would service delivery look like for a knowledge-based professional who treats clients as co-equal partners? Can provocative and counter- 
intuitive approaches to service delivery be uncovered that represent keys as to why some professionals are so outstanding in their practice? Exploring the implications when professionals shift in their workbased self-concept, client-images and views of the service-exchange would greatly enhance our understanding of why professionals differ in their approaches. We could answer, for example, whether service professionals who hold multiple, loose identities in flexible tension better adapt their images and behaviors to meet clients' needs, or, alternatively, whether this shifting represents an inauthentic way of delivering an expertise that is clearly apparent to clients. The ideas offered in this paper represent a springboard for future work investigating the professional-client relationship, an under-explored but exciting line of study, and one which has important and immediate implications for both research and practice.

\section{Conclusion}

In this paper, we theoretically explored the ways in which service professionals may approach delivering their knowledge-based expertise. Through applying concepts from social and organizational identity theories, we offered rationale as to why service professionals may identify with firm membership, and the related work-based self-concepts and images of their clients they likely form. We argued that identification with organizational membership also drives the types of service exchanges professionals create with their clients and the type of clientele they may develop. Our work adds depth and texture to our understanding of the complex phenomenon of expert-based service delivery and we hope, acts as a catalyst for future research and practice.

\section{References}

Abbott, A. (1988), The System of Professions, University of Chicago Press, Chicago, IL.

Abrams, D. and Hogg, M.A. (1990), "An introduction to the social identity approach", in Abrams, D. and Hogg, M.A. (Eds), Social Identity Theory: Constructive and Critical Advances, Springer, New York, NY, pp. 1-9.

Albert, S. and Whetten, D.A. (1985), “Organizational identity”, in Cummings, L.L. and Staw, B.M. (Eds), Research in Organizational Behavior, Vol. 7, JAI Press, Greenwich, CT, pp. 263-95.

Ashforth, B.E. and Mael, F.A. (1996), “Organizational identity and strategy as a context for the individual", in Shrivastava, P., Huff, A.S. and Dutton, J.E. (Eds), Advances in Strategic Management, Vol. 13, JAI Press, Greenwich, CT, pp. 19-64. 
Barber, B. (1965), "Some problems in the sociology of professions", in Lynn, K.S. (Ed.), The Professions in America, 2nd ed., Houghton Mifflin, Boston, MA, pp. 15-34.

Barney, J.B. (1991), "Firm resources and sustained competitive advantage", Journal of Management, Vol. 17, pp. 99-120.

Bartel, C.A. (2001), "Social comparisons in boundary-spanning work: effects of community outreach on members' organizational identity and identification", Administrative Science Quarterly, Vol. 46, pp. 379-413.

Becker, G.S. (1993), Human Capital, 3rd ed., University of Chicago Press, Chicago, IL.

Benner, P. and Wrubel, J. (1989), The Primacy of Caring: Stress and Coping in Health and IIIness, Addison-Wesley, Menlo Park, CA.

Berry, L.L. (1995), "Relationship marketing of services: growing interest, emerging perspectives", Journal of the Academy of Marketing Science, Vol. 23, pp. 236-45.

Berry, L.L. and Parasuraman, A. (1991), Marketing Services, The Free Press, New York, NY.

Bitner, M.J., Booms, B.H. and Tetreault, M.S. (1990), "The service encounter: diagnosing favorable and unfavorable incidents", Journal of Marketing, Vol. 54, pp. 71-84.

Bitner, M.J., Faranda, W.T., Hubbert, A.R. and Zeithaml, V.A. (1997), “Customer contributions and roles in service delivery", International Journal of Service Industry Management, Vol. 8, pp. 193-205.

Black, J.A. and Boal, K.B. (1994), "Strategic resources: traits, configurations and paths to sustainable competitive advantage", Strategic Management Journal, Vol. 15, pp. 131-48.

Bowen, D.E. (1986), "Managing customers as human resources in service organizations", Human Resource Management, Vol. 25, pp. 371-83.

Bowen, D.E. and Jones, G.R. (1986), "Transaction cost analysis of service organization-customer exchange", Academy of Management Review, Vol. 11, pp. 428-41.

Bowen, D.E. and Lawler, E.E. (1992), "The empowerment of service workers: what, why how and when", Sloan Management Review, Vol. 33, pp. 31-9.

Bowen, D.E. and Lawler, E.E. (1995), “Empowering service employees”, Sloan Management Review, Vol. 36, pp. 73-84.

Bowen, D.E., Gilliland, S.W. and Folger, R. (1999), "How being fair with employees spills over to customers", Organizational Dynamics, Winter, pp. 7-23.

Bowen, J. and Ford, R.C. (2002), “Managing service organizations: does having a 'thing' make a difference?", Journal of Management, Vol. 28, pp. 447-69. 
Brewer, M.B. (1991), "The social self: on being the same and different at the same time", Personality and Social Psychology Bulletin, Vol. 17, pp. 475-82.

Brewer, M.B. and Pierce, K.P. (2005), "Social identity complexity and outgroup tolerance", Personality and Social Psychology Bulletin, Vol. 31, pp. 428-37.

Broderick, A.J. (1999), "Role theory and the management of service encounters", The Services Industries Journal, Vol. 19, pp. 117-31.

Brown, S.W. and Swartz, T.A. (1989), "A gap analysis of professional service quality”, Journal of Marketing, Vol. 53, pp. 92-8.

Bunderson, J.S., Lofstrom, S.M. and van de Ven, A.H. (2000), “Conceptualizing and measuring professional and administrative models of organizing", Organizational Research Methods, Vol. 3, pp. 366-91.

Carr-Saunders, A. and Wilson, P.A. (1941), The Professions, Clarendon Press, Oxford.

Charon, J.M. (1992), Symbolic Interactionism, Prentice-Hall, Englewood Cliffs, NJ.

Chase, M. (1998), "HMOs send doctors to school to polish bedside manners", Wall Street Journal, April 13, p. B1.

Clark, T. and Salaman, G. (1998), “Creating the 'right' impression: towards a dramaturgy of management consulting", The Services Industry Journal, Vol. 18, pp. 18-38.

Coff, R.W. (1997), "Human assets and management dilemmas: coping with hazards on the road to resource-based theory", Academy of Management Review, Vol. 22, pp. 374-402.

Coff, R.W., Coff, E. and Eastvold, R. (2006), "The knowledge leveraging paradox: how to scale up without making knowledge imitable", Academy of Management Review, Vol. 31, pp. 452-65.

Corley, K.G. (2004), "Defined by our strategy or our culture? Hierarchical differences in perceptions of organizational identity and change", Human Relations, Vol. 57, pp. 1145-77.

Corley, K.G., Harquail, C.V., Pratt, M.G., Glynn, M.A., Fiol, C.M. and Hatch, M.J. (2006), “Guiding organizational identity through aged adolescence", Journal of Management Inquiry, Vol. 15, pp. 85-99.

Covaleski, M.A., Dirsmith, M.W., Heian, J.B. and Samuel, S. (1998), "The calculated and the avowed: techniques of discipline and struggles over identity in Big Six public accounting firms", Administrative Science Quarterly, Vol. 43, pp. 293-327.

Coxe, W., Hartung, N.F., Hochberg, H., Lewis, B.J., Maister, D.H., Mattox, R.F. and Piven, P.A. (1987), Success Strategies for Design Professionals, McGraw-Hill, New York, NY. 
Cronin, J.J. and Taylor, S.A. (1992), "Measuring service quality: a reexamination and extension", Journal of Marketing, Vol. 56, pp. 55-68.

Dabholkar, P.A. and Overby, J.W. (2005), "Linking process and outcome to service quality and customer satisfaction evaluations", International Journal of Service Industry Management, Vol. 16, pp. 1027.

DeSteno, D. and Salovey, P. (1997), "Structural dynamism in the concept of self: a flexible model for a malleable concept", Review of General Psychology, Vol. 1, pp. 389-409.

Douglas, T.J. and Ryman, J.A. (2003), “Understanding competitive advantage in the general hospital industry: evaluating strategic competencies", Strategic Management Journal, Vol. 24, pp. 33347.

Dukerich, J.M., Golden, B.R. and Jacobson, C.K. (1996), “Nested cultures and identities: a comparative study of nation and professional/occupation status effects on resource allocation decisions", in Bamberger, P.A., Erez, M. and Bacharach, S.B. (Eds), Research in the Sociology of Organizations, Vol. 14, JAI Press, Greenwich, CT, pp. 35-89.

Dukerich, J.M., Golden, B.R. and Shortell, S.M. (2002), "Beauty is in the eye of the beholder: the impact of organizational identification, identity and image on the cooperative behaviors of physicians", Administrative Science Quarterly, Vol. 47, pp. 507-33.

Dutton, J.E., Dukerich, J.M. and Harquail, C.V. (1994), “Organizational images and member identification", Administrative Science Quarterly, Vol. 39, pp. 239-63.

Ericson, E.H. (1980), Identity and the Life Cycle, Norton, New York, NY.

Garbarino, E. and Johnson, M.S. (1999), "The different roles of satisfaction, trust and commitment in customer relationships", Journal of Marketing, Vol. 63, pp. 70-87.

Gioia, D.A. (1998), “From individual to organizational identity”, in Whetten, D.A. and Godfrey, P.C. (Eds), Identity in Organizations: Building Theory through Conversations, Sage, Thousand Oaks, CA, pp. $17-31$.

Grant, R.B. (1996), "Towards a knowledge-based theory of the firm", Strategic Management Journal, Vol. 17, pp. 109-22.

Greenwood, R. and Empson, L. (2003), "The professional partnership: relic or exemplary form of governance?", Organization Studies, Vol. 24, pp. 909-33.

Grey, C. (1988), "On being a professional in a 'big six' firm”, Accounting, Organizations and Society, Vol. 23, pp. 569-87. 
Griesinger, D.W. (1990), "The human side of economic organization", Academy of Management Review, Vol. 15, pp. 478-99.

Guenzi, P. and Pelloni, O. (2004), "The impact of interpersonal relationships on customer satisfaction and loyalty to the service provider", International Journal of Service Industry Management, Vol. 15, pp. 365-84.

Gutek, B.A. (1995), The Dynamics of Service, Jossey-Bass, San Francisco, CA.

Gutek, B.A., Groth, M. and Cherry, B. (2002), “Achieving service success through relationships and enhanced encounters", Academy of Management Executive, Vol. 16, pp. 132-45.

Gutek, B.A., Bhappu, A.D., Liao-Troth, M.A. and Cherry, B. (1999), "Distinguishing between service relationships and encounters", Journal of Applied Psychology, Vol. 84, pp. 218-33.

Gutek, B.A., Cherry, B., Bhappu, A.D., Schneider, S. and Woolf, L. (2000), "Features of service relationships and encounters", Work and Occupations, Vol. 27, pp. 319-52.

Gwinner, K.P., Gremler, D.D. and Bitner, M.J. (1998), "Relational benefits in services industries: the customer's perspective", Academy of Marketing Science, Vol. 26, pp. 101-14.

Hanlon, G. (1997), “A shifting professionalism: accountancy”, in Broadbent, J., Dietrich, M. and Roberts, J. (Eds), The End of the Professions? The Restructuring of Professional Work, Routledge, London, pp. 123-39.

Haug, M.R. (1994), "Elderly patients, caregivers and physicians: theory and research", Journal of Health and Social Behavior, Vol. 35, pp. 1-14.

Hewitt, J.P. (1989), Dilemmas of the American Self, Temple University Press, Philadelphia, PA.

Hitt, M.A., Bierman, L., Shimizu, K. and Kochhar, R. (2001), "Direct and moderating effects of human capital on strategy and performance in professional service firms: a resource-based perspective", Academy of Management Journal, Vol. 44, pp. 13-26.

Hofer, C.W. and Schendel, D. (1978), Strategy Formulation: Analytic Concepts, West, St. Paul, MN. Hogg, M.A. and Abrams, D. (1988), Social Identifications, Routledge, New York, NY.

Hogg, M.A. and Abrams, D. (1990), "Social motivation, self esteem and identity", in Abrams, D. and Hogg, M.A. (Eds), Social Identity Theory: Constructive and Critical Advances, Springer, New York, NY, pp. 28-47.

Hogg, M.A. and McGarty, C. (1990), "Self categorization and social identity", in Abrams, D. and Hogg, M.A. (Eds), Social Identity Theory: Constructive and Critical Advances, Springer, New York, NY, pp. 10-27. 
Hogg, M.A., Terry, D.J. and White, K.M. (1995), "A tale of two theories: a critical comparison of identity theory and social identity theory", Social Psychology Quarterly, Vol. 58, pp. 255-69.

Hughes, E.C. (1965), "Professions", in Lynn, K.S. (Ed.), The Professions in America, 2nd ed., Houghton Mifflin, Boston, MA, pp. 1-14.

Jaakkola, E. and Halinen, A. (2006), "Problem solving within professional services: evidence from the medical field", International Journal of Service Industry Management, Vol. 17, pp. 409-29.

Karantinou, K.M. and Hogg, M.K. (2001), “Exploring relationship management in professional services: a study of management consultancy", Journal of Marketing Management, Vol. 17, pp. 263-86.

Kramer, R.M. (1991), “Intergroup relations and organizational dilemmas: the role of categorization processes", in Staw, B.M. and Cummings, T.G. (Eds), Research in Organizational Behavior, Vol. 13, JAI Press, Greenwich, CT, pp. 191-228.

Kreiner, G.E. and Ashforth, B.E. (2004), "Evidence toward an expanded model of organizational identification", Journal of Organizational Behavior, Vol. 25, pp. 1-27.

Lane, P.J. and Lubatkin, M. (1998), "Relative absorptive capacity and interorganizational learning", Strategic Management Journal, Vol. 19, pp. 461-77.

Leidner, R. (1993), Fast Food, Fast Talk: Service Workers and the Routinization of Everyday Life, University of California Press, Berkeley, CA.

Levinthal, D.A. and Fichman, M. (1988), “Dynamics of interorganizational attachments: auditor-client relationships", Administrative Science Quarterly, Vol. 33, pp. 345-69.

McGivern, C. (1983), "Some facets of the relationship between consultants and clients in organizations", Journal of Management Studies, Vol. 20, pp. 367-86.

McLean Parks, J., Kidder, D.L. and Gallagher, D.G. (1998), “Fitting square pegs into round holes: mapping the domain of contingent work arrangements onto the psychological contract", Journal of Organizational Behavior, Vol. 19, pp. 697-730.

Maister, D. (1993), Managing the Professional Services Firm, The Free Press, New York, NY.

Makhija, M. (2003), "Comparing the resource-based and market-based views of the firm: empirical evidence from Czech privatization", Strategic Management Journal, Vol. 24, pp. 433-51.

Mars, G. and Nicod, M. (1984), The World of Waiters, George Allen, Boston, MA.

Mills, P., Hall, J., Leidecker, J. and Marguilies, N. (1983), "Flexform: a model for professional service organizations", Academy of Management Review, Vol. 8, pp. 118-31. 
Morris, T. and Empson, L. (1998), “Organization and expertise: an exploration of knowledge bases and the management of accounting and consulting firms", Accounting, Organizations and Society, Vol. 23, pp. 609-24.

Mowery, D.C., Oxley, J.E. and Silverman, B.S. (1996), "Strategic alliances and interfirm knowledge transfer", Strategic Management Journal, Vol. 17, pp. 77-91.

Nelson, R.R. and Winter, S.G. (1982), An Evolutionary Theory of Economic Exchange, Belknap Press, Cambridge.

Noddings, N. (1984), Caring: A Feminist Approach to Ethics and Moral Education, The University of California Press, Berkeley, CA.

Nonaka, I. (1994), “A dynamic theory of knowledge creation", Organization Science, Vol. 5, pp. 14-37.

Old, D.R. (1995), “Consulting for real transformation, sustainability and organic form”, Journal of Organizational Change Management, Vol. 8, pp. 6-17.

Parasuraman, A., Zeithaml, V.A. and Berry, L.L. (1985), "A conceptual model of service quality and its implications", Journal of Marketing, Vol. 49, pp. 41-50.

Parasuraman, A., Zeithaml, V.A. and Berry, L.L. (1988), "SERVQUAL: a multiple-item scale for measuring consumer perceptions of service quality", Journal of Retailing, Vol. 64, pp. 12-40.

Peteraf, M.A. (1993), "The cornerstones of competitive advantage: a resource based view", Strategic Management Journal, Vol. 14, pp. 179-91.

Pettigrew, T.F. (1986), "The intergroup contact proposition reconsidered", in Hewstone, M. and Brown, R. (Eds), Contact and Conflict in Intergroup Encounters, Basil Blackwell, New York, NY, pp. 16995.

Pfeffer, J. and Salancik, G. (1978), The External Control of Organizations, Harper \& Row, New York, NY.

Pierce, J. (1995), Gender Trails: Emotional Lives in Contemporary Law Firms, University of California Press, Berkeley, CA.

Pierce, J. (1996), "Rambo litigators: emotional labor in a male-dominated occupation", in Cheng, C. (Ed.), Masculinities in Organizations, Sage, Thousand Oaks, CA, pp. 1-28.

Pilkington, A. and Chai, K. (2007), "Research themes, concepts and relationships", International Journal of Service Industry Management, Vol. 19, pp. 83-110.

Pratt, M.G. (1998), "To be or not to be? Central questions in organizational identification", in Whetten, D.A. and Godfrey, P.C. (Eds), Identity in Organizations: Building Theory through Conversations, Sage, Thousand Oaks, CA, pp. 171-207. 
Pratt, M.G. (2000), "Classifying managerial responses to multiple organizational identities", Academy of Management Review, Vol. 25, pp. 18-42.

Pratt, M.G. and Rafaeli, A. (1997), "Organizational dress as a symbol of multilayered social identities", Academy of Management Journal, Vol. 40, pp. 862-98.

Rafaeli, A. (1989), "When cashiers meet customers: an analysis of the role of supermarket cashiers", Academy of Management Journal, Vol. 32, pp. 245-73.

Reed, R. and DeFillippi, R.J. (1990), "Causal ambiguity, barriers to imitation and sustainable competitive advantage", Academy of Management Review, Vol. 15, pp. 88-102.

Reichhold, F. (1993), "Loyalty-based management", Harvard Business Review, Vol. 71, pp. 64-74.

Reihlen, M. and Apel, B.A. (2007), "Internationalization of professional services as learning - a constructivist approach", International Journal of Service Industry Management, Vol. 18, pp. 140-51.

Reitzes, D.C. and Mutran, E.J. (2002), "Self-concept as the organization of roles: importance, centrality and balance", Sociological Quarterly, Vol. 43, pp. 647-67.

Rust, R.T. and Zahorik, A. (1993), “Customer satisfaction, customer retention and market share”, Journal of Retailing, Vol. 69, pp. 193-215.

Saura, I.R., Contri, G.B., Taulet, A.C. and Velazquez, B.M. (2005), "Relationships among customer orientation, service orientation and job satisfaction in financial services", International Journal of Service Industry Management, Vol. 16, pp. 497-525.

Schein, E.H. (1997), "The concept of 'client' from a process consultation perspective", Journal of Organizational Change Management, Vol. 19, pp. 2102-66.

Schlenker, B.R. (1980), Impression Management: The Self Concept, Social Identity and Interpersonal Relations, Brooks/Cole, Monterey, CA.

Schneider, B., Parkington, J.J. and Buxton, V.M. (1980), "Employee and customer perceptions of service in banks", Administrative Science Quarterly, Vol. 24, pp. 638-49.

Seiders, K. and Berry, L.L. (1998), "Service fairness: what it is and why it matters", Academy of Management Executive, Vol. 12, pp. 8-20.

Sharma, N. and Patterson, P.G. (1999), "The impact of communication effectiveness and service quality on relationship commitment in consumer, professional services", The Journal of Services Marketing, Vol. 13, pp. 151-70. 
Sharma, N. and Patterson, P.G. (2000), "Switching costs, alternative attractiveness and experience as moderators of relationship commitment in professional, consumer services", International Journal of Service Industry Management, Vol. 11, pp. 470-90.

Solomon, M.R., Surpremant, C., Czepiel, J.A. and Gutman, E.G. (1985), “A role theory perspective on dyadic interactions: the service encounter", Journal of Marketing, Vol. 49, pp. 99-111.

Sutton, R.I. and Rafaeli, A. (1988), "Untangling the relationship between displayed emotions and organizational sales: the case of convenience stores", Academy of Management Journal, Vol. 31, pp. 461-87.

Svensson, G. (2006), "New aspects of research into service encounters and service quality", International Journal of Service Industry Management, Vol. 17, pp. 245-57.

Tajfel, H. (1982), Social Identity and Intergroup Relations, Cambridge University Press, Cambridge.

Tajfel, H. and Turner, J.C. (1985), "The social identity theory of intergroup behavior", in Worchel, S. and Austin, W.G. (Eds), Psychology of Intergroup Relations, 2nd ed., Nelson-Hall, Chicago, IL, pp. 724.

Teece, D.J., Pisano, G. and Shuen, A. (1997), "Dynamic capabilities in strategic management", Strategic Management Journal, Vol. 18, pp. 509-34.

Thoits, P.A. (1991), "On merging identity theory and stress research", Social Psychological Quarterly, Vol. 54, pp. 101-12.

Trice, H.M. (1993), Occupational Subcultures in the Workplace, ILR Press, Ithaca, NY.

Troyer, L., Mueller, C.W. and Osinsky, P.I. (2000), "Who's the boss? A role-thematic analysis of customer work", Work and Occupations, Vol. 27, pp. 406-27.

Turner, J.C. (1982), "Towards a cognitive redefinition of the social group", in Tajfel, H. (Ed.), Social Identity and Intergroup Relations, Cambridge University Press, Cambridge, pp. 15-40.

Turner, J.C., Hogg, M.A., Oakes, P.J., Reicher, S.D. and Wetherell, M. (1987), Rediscovering the Social Group: A Self-categorization Theory, Blackwell, Oxford.

Tyler, T.R. (1999), "Why people cooperate with organizations: an identity-based perspective", in Sutton, R.I. and Staw, B.M. (Eds), Research in Organizational Behavior, Vol. 21, JAI Press, Greenwich, CT, pp. 201-47.

US Bureau of Economic Analysis (2006), available at: www.bea.gov

van Maanen, J. and Barley, S.R. (1984), “Occupational communities: control in organizations”, in Staw, B.M. and Cummings, L.L. (Eds), Research in Organizational Behavior, Vol. 6, JAI Press, Greenwich, CT, pp. 287-365. 
Varva, T.G. (1992), After marketing: How to Keep Customers for Life through Relationship Marketing, Irwin, Homewood, IL.

Verma, R. (2000), “An empirical analysis of management challenges in service factories, service shops, mass services and professional services", International Journal of Service Industry Management, Vol. 11, pp. 8-25.

Whetten, D.A. (2006), "Albert and Whetten revisited: strengthening the concept of organizational identity", Journal of Management Inquiry, Vol. 15, pp. 219-34.

Winch, G. and Schneider, E. (1993), “Managing the knowledge-based organization: the case of architectural practice", Journal of Management Studies, Vol. 30, pp. 923-37.

Winter, M.F. (1988), The Culture and Control of Expertise, Greenwood Press, New York, NY. 